\title{
University students' perceptions of their abilities relate to their entrepreneurial intent
}

\author{
Hannu Räty and Katri Komulainen \\ Department of Education and Psychology, \\ University of Eastern Finland, Joensuu, Finland \\ Ulla Hytti \\ Department of Management and Entrepreneurship, Turku School of Economics, \\ University of Turku, Turku, Finland \\ Kati Kasanen and Päivi Siivonen \\ Department of Education and Psychology, \\ University of Eastern Finland, Joensuu, Finland, and \\ Inna Kozlinska \\ University of Groningen, Groningen, The Netherlands and \\ RISEBA University of Business, Arts and Technology, Riga, Latvia
}

\begin{abstract}
Purpose - The purpose of this paper is to examine to what extent Finnish university students endorse entrepreneurial intent and the ways in which they position themselves in relation to entrepreneurship according to their self-perceived abilities or "ability self".

Design/methodology/approach - The study was conducted by means of an e-survey, and the participants comprised the sample of students $(n=1,819)$ from two Finnish universities, representing diverse fields of study. Findings - It was found that a great majority of the students showed a relatively low intent to become an entrepreneur. The perception of abilities, such as innovativeness and ambitiousness-competitiveness, was positively related with entrepreneurial intent, whereas the perception of academic abilities and "conventional" employee skills indicated inverse associations.

Social implications - The findings suggest that in terms of self-perceived abilities, entrepreneurship in an academic context is perceived as a rather restricted category to which only a few specific individuals have access. Accordingly, there is a certain tension between the tenets of entrepreneurship and corresponding abilities, and the ethos of universities and related high-valued abilities such as theoreticality and criticality. Originality/value - Although employability and entrepreneur intent have been widely studied, little is known about students' identification with entrepreneurship according to their ability perceptions. The present study contributes to the existing body of knowledge on university students' "internal employability" that involves students' self-assurance and views of work-related relevance with regard to supposed abilities.

Keywords Employability, University students, Entrepreneurial intent

Paper type Research paper

\section{Introduction}

As Vivas and Alvarez-Hevia (2017) maintained in their recent review, the transition process of university graduates from university to working life has changed significantly during the past decade in many European countries. Career paths are increasingly defined by

(c) Hannu Räty, Katri Komulainen, Ulla Hytti, Kati Kasanen, Päivi Siivonen and Inna Kozlinska. Published by Emerald Publishing Limited. This article is published under the Creative Commons Attribution (CC BY 4.0) licence. Anyone may reproduce, distribute, translate and create derivative works of this article (for both commercial \& non-commercial purposes), subject to full attribution to the original publication and authors. The full terms of this licence may be seen at http://creativecommons.org/licences/by/4.0/legalcode

The work was supported by the Academy of Finland under grand 295961.
\end{abstract}

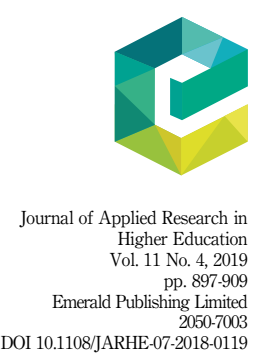

Received 5 July 2018 Revised 13 December 2018

25 February 2019 1 April 2019 Accepted 2 April 2019 intent

(


JARHE 11,4 flexibility and mobility, and, as part of this trend, the ideas of self-employment and entrepreneurship are specifically encouraged (see also Prokou, 2008; Boden and Nedeva, 2010; Wood, 2011). Referring to the Finnish context, Ahola (2001) even argued that in the context of atypical employment relationships and in conditions of uncertainty and risk, the transition itself has become an enterprising effort for university graduates.

For an individual student, the change implies a (re)consideration of his or her employability in the labour market (e.g. Tomlinson, 2008, 2012). This includes an appraisal of an individual's self-perceived abilities in relation to current expectations, such as a call for entrepreneurship. Graduates must make such an evaluation in a situation in which the supposed requirements of work are often seen to be in conflict with established academic qualifications and values (e.g. Komulainen et al., 2012). The present survey set out to scrutinise the ways in which Finnish university students position themselves in relation to entrepreneurship, representing an emerging set of ability requirements. Specifically, we focussed on the ways in which students' perceptions of their own abilities, "ability self", concur with their entrepreneurship intent. Accordingly, the present study contributes to the existing body of knowledge on university students' "internal employability" that involves students' self-assurance and views of work-related relevance with regard to supposed abilities (Rothwell et al., 2008).

Even though entrepreneurial intent has been widely studied, little is known about students' identification with entrepreneurship according to their ability perceptions. Previous research has mainly focussed on the relationship between entrepreneurial self-efficacy and perceived behavioural control. Research has investigated the degree to which individuals' beliefs in their abilities to successfully start a company and their perceived control of the outcomes of becoming an entrepreneur are positively related to entrepreneurial intent, as measured by students' deliberative intents to set up a firm (e.g. Schlaegel and Koenig, 2014). However, our proposed contribution explores the relationship between students' perceptions of their abilities and their entrepreneurial intent, i.e. a broader personal orientation towards starting a venture and planning to do so at some point in the future (Thompson, 2009).

Much of the theorizing on entrepreneurial intent derives from the model of planned behaviour developed by Ajzen (1991), which has shown that intent is a significant predictor of entrepreneurial activity and venture initiation (e.g. Engle et al., 2010; Goethrer et al., 2012). However, we did not employ this particular model as our theoretical framework and did not focus on the association between students' entrepreneurial intent and their consequent behaviour, but rather we applied the notion of intent as a conceptually pertinent and practical operationalization to measure students' entrepreneurial positioning. Furthermore, by including academic, social, enterprising and other abilities, this study broadens the set of self-assessed predictors of intent known to date from earlier studies based on Ajzen's theory.

Regarding our theoretical framework, we first focus on the current discourse of academic employability and two different approaches to study the role of abilities in students' perceptions of their employability, including entrepreneurship. Next, we address our major theoretical concept, ability self and its contribution to an individual's appraisals of his or her prospects in the labour market. Finally, research problems and related expectations are given.

\section{Theoretical framework}

Although entrepreneurship is increasingly appreciated in many countries, people tend to have a relatively low personal motivation to become an entrepreneur (e.g. Ozaralli and Rivenburgh, 2016; for a review of Finnish findings, see Tonttila, 2010; Nurmi and Paasio, 2007). Even in the North American context, students have mixed feelings about entrepreneurship as a career, and only a few aim to pursue an entrepreneurial career directly after graduation (Hisrich and Peters, 2002). Parents, who have an important role in the 
shaping of their children's educational and vocational choices, also quite rarely see it as likely that their child would become an entrepreneur; this also applies to Finnish academically educated parents, who otherwise have relatively positive attitudes towards entrepreneurship education (Räty et al., 2016).

According to a recent large-scale survey conducted in Finland by the Union of Academic Employees (Akava, 2016), a great majority of university-educated young people indicated that they would prefer to work as employees (69 per cent) rather than as entrepreneurs ( 8 per cent). What they want most of all in working life is stability and safety rather than advancement in career, increasing income or possibilities to function in international environments.

Spanish graduates also still perceive a gap between the labour market and higher education, and they have difficulties recognising some of the most-required competencies (Vivas and Alvarez-Hevia, 2017). Interview findings obtained from the Finnish context suggested that some individuals with a university degree in precarious work situations may question whether a university education amounts to a personal merit of which they can be unequivocally proud (Siivonen et al., 2016). However, many feel that the completion of an academic degree attests to the fact that they possess valuable theoretical abilities that can be applied broadly in working life (Räty, 2015).

Evidently, the current discourse on employability is apt to challenge the value of traditional academic credentials, "hard currencies", by emphasising technical, social and personal characteristics that are not based on university degrees as such (Tomlinson, 2008). This also seems to be the case in the Finnish context (e.g. Komulainen et al., 2012), in which the need to advance work-relevant competences is emphasised in higher education policy, following an international trend of "entrepreneurialism" (Gareth and Kitaev, 2005).

There are at least two major ways to study employability of university graduates. First, academic employability can be defined as possessing a constellation of personal abilities that steer individuals towards proactive adaptability specific to work and careers (Coetzee, 2017). For example, there are research findings which indicate that personal attributes such as optimism, innovativeness, risk-taking propensity, need for achievement, generalised selfefficacy, stress tolerance, need for autonomy and active personality are linked with entrepreneurial intent (e.g. Ozaralli and Rivenburgh, 2016; Rauch and Frese, 2007; Karabulut, 2016).

Second, academic employability can also be approached through students' own perceptions of their current abilities and following subjective prospects in working life (e.g. Rothwell et al., 2008). The present study adopted this particular point of view, i.e. focussing on students' perceptions of their existing skills. These perceptions can be defined as the part of an individual's self-concept, "ability self", which relates to the individual's evaluations of his/her abilities and other characteristics, understood as more or less internal and constant personal features which orientate an individual towards education, work and career (Komulainen et al., 2012).

Even though ability self is expressed in terms of personal qualities, as "ability talk", which makes it such a convincing individualising mode of interpretation, the formation of an ability self is connected with an individual's life-historical positions (such as gender and class) and institutional contexts (e.g. Brookover et al., 1964). In the present study, institutional context refers to the predominant social and cultural representations of intelligence maintained by the educational system and labour market (e.g. Mugny and Carugati, 1989).

University graduates are invited, and even required, to position themselves in the representations of abilities required in working life. Even if the pressures generated by these normative requests do not necessarily lead a student to reconstruct his/her present "ability self", they connect him or her to socially constructed frameworks and act as vantage points 
JARHE 11,4

900 that a student is both aware of and must take into account (cf. Clémence, 2001). An individual's ability self provides a self-representational position that presumably organises a subjectively interpreted "fit" in the labour market that then shows up in students' employability optimism (Räty et al., 2018; Komulainen et al., 2012). Ability representations derived from the current discourse of labour market may even generate uncertainty of one's prospects despite the fact that the actual possibilities to become employed are fairly good for most of the graduates, as suggested by a recent large-scale Finnish survey (Kurlin, 2018).

In terms of content, abilities that have emerged in recent discourse about employability can be classified in numerous ways (e.g. Coetzee, 2017). In this study, the independent variable, the concept of "ability self", is derived from previous studies which reviewed both the field-specific research and the related public discussions on the employability skills needed in present-day labour markets (Komulainen et al., 2012). First, the authors identified those ability domains that were highlighted in public discussions. Further, the final selection of ability domains tested in a pilot study was based on the following provisional categorisation: social skills, extroversionintroversion, enterprising skills, academic abilities and conventional attributes of a good employee (Räty et al., 2018). Far from representing an exhaustive list, these domains can be judged to represent a set of abilities, familiar to students themselves, through which ability requirements have been addressed in public discussion.

Regarding the dependent variable, entrepreneurial intent, we examined students' positioning with regard to working life on the basis of self-acknowledged opinions about their readiness to establish their own businesses in the future (Thompson, 2009). Accordingly, for university graduates, entrepreneurial intent reflects their career choice behaviour (Kautonen et al., 2015; Lee-Ross, 2017).

In summary, the present study examined students' positioning towards entrepreneurship in terms of their self-perceived abilities. The question was asked what sorts of self-perceived abilities are associated with entrepreneurial intent. In line with the predominant employability discourse it was expected that features denoting extroversion, ambitiousness, competitiveness, risk taking and innovativeness in particular would show a positive association with entrepreneurial intent. Further, given that academic abilities are still an essential part of students' academic identity, it was quite plausible to expect that these abilities would indicate even some contrary associations. In addition, our data gave us an opportunity to examine the extent to which Finnish university students are inclined to opt for becoming an entrepreneur, measured by their entrepreneurial intent.

\section{Research methodology}

\subsection{Participants}

The survey was targeted at students from the multi-disciplinary Universities of Eastern Finland and Turku, which are located in different regional settings. As we tried to get a group that was as heterogenous as possible in terms of students' fields of study, dissimilar study fields were targeted in these two universities. At the University of Eastern Finland, the Faculty of Social Sciences and Business Studies and the Faculty of Science and Forestry were included; and at the University of Turku, the Faculty of Medicine and the Faculty of Humanities were included. Based on the faculties' records, the students' major fields of study were determined, and the questionnaires were distributed to all students doing their MA degree, which usually takes approximately five years to complete. Foreign students, postgraduate students and those who did not give permission to use their names in surveys were excluded. The study was conducted by means of e-survey. The students were requested to complete the questionnaire on a voluntary basis and anonymously. The questionnaire took around 10-15 min to complete. After two days from the first circulation, the students were sent the first reminder, and the second reminder was sent after one week. 
The response rate was 24 per cent. Of those who responded, 67 per cent were female and 33 per cent male, i.e. the females were somewhat more active, as the corresponding shares in the initial student population were 58 and 42 per cent, respectively. Students of the University of Eastern Finland (26 per cent) were more active than those of the University of Turku (20 per cent). With regard to the faculties, the highest response rate was obtained from the fields of the Faculty of Social Sciences and Business Studies (27 per cent) and the lowest from the fields of the Faculty of Humanities (19 per cent).

The participants comprised a sample of students, totalling 1,819, at the University of Eastern Finland $(n=1,387)$ and the University of Turku $(n=421)$, and unidentified cases $(n=11)$. Participant age varied between 18 and 60 years (mean age 29.4, SD =9.3). The following 10 fields were represented: social sciences $(n=438)$, business studies $(n=289)$, law $(n=295)$, natural sciences (chemistry, physics and mathematics, $n=108)$, computing science $(n=82)$, forest sciences and biology $(n=164)$, medicine $(n=112)$, nursing science $(n=45)$, languages $(n=120)$, humanities $(n=139)$ and unspecified $(n=27)$.

On average, 40 per cent of the participants estimated that they had already completed 75-100 per cent of their degree, whereas 19 per cent estimated that they have completed less than 24 per cent. Almost one third (31 per cent) reported having a previous university degree. With regard to working life experience, 70 per cent of the participants reported having at least one year of experience, 13 per cent had from 1 month to 11 months, and 9 per cent had no working experience at all.

\subsection{Measurements}

The questionnaire comprised the following measures.

Entrepreneurial intent. The questionnaire included four characteristic statements derived from previous studies on entrepreneurial intent pertaining to career choice behaviour (cf. Kautonen et al., 2015; Krueger et al., 2000). The rating scale for three of the statements was anchored by "very improbable" (1) and "very probable" (5). The three statements were: "how probable is it that you would at some time try to function as an entrepreneur?"; "how probable is it that you will become an entrepreneur after you have gained an appropriate amount of work experience?"; and "how probable is it that you will establish your own enterprise during some phase of your career?" The scale for the fourth statement was anchored by "no intent at all" (1) and "very strong intent" (5): "how strong is your intent to become an entrepreneur at some point of your career?" A mean scale was constructed $(M=2.47, \mathrm{SD}=1.14)$, of which the reliability coefficient (Cronbach's $\alpha)$ was 0.97 and the item-scale correlations varied between 0.90 and 0.92. All four statements are loaded on the same factor.

Perceptions of own abilities. The measure applied in the present study is derived from Komulainen et al., 2015 and their work on employability skills further piloted by Räty et al., 2018. This measure consisted of six factor-analytically derived dimensions which included: extroversion (e.g. "talkative", "skilled at building contacts" and reversed "prefers to listen"), $\alpha=0.86$; mental strength (e.g. "good stress tolerance", "strong self-confidence" and "copes with failures"), $\alpha=0.72$; innovativeness (e.g. "rule-breaking", "innovative" and "likes risk-taking"), $\alpha=0.72$; ambitious-competitiveness (e.g. "ambitious", "competitive" and "goal-oriented"), $\alpha=0.71$; conventional employee skills (e.g. "conscientious", "honest" and "has cooperative skills"), $\alpha=0.61$; and academic abilities (e.g. "theoretical", "critical" and "intelligent"), $\alpha=0.49$; despite its modest reliability, the scale of academic abilities was included because of its theoretical interest.

As the descriptive statistics in Table I indicated, the students responded to the statements pertaining to the entrepreneurial intent scale in a quite systematic way, since the shares of different alternatives were rather similar between the statements. About one fifth 


\section{JARHE 11,4}

Fairly

improbable improbable "between"
Fairly Very

probable probable Mean SD

How probable is it that you would at some time try to function as an entrepreneur? $396(22)$ 567 (31) $401(22)$

279 (15) 169 (9)

is it that you will become an entrepreneur after you have gained an appropriate amount of work experience?

$409(23)$
588 (33)

$223(12)$

$130(7)$

Table I.

Frequencies, means and standard deviations of responses to the statements indicating entrepreneurial intent (percentages in parentheses) establish your own enterprise during some phase of your career?

How strong is your intention to become an entrepreneur at some point of your career?

$\begin{array}{ll}465(26) & 581(32) \\ \text { No } & \text { Not much } \\ \text { intention } & \text { intention }\end{array}$

$\begin{array}{lllll}386(21) & 181(13) & 121(7) & 2.36 & 1.16 \\ \text { "between” } & \text { Fairly } & \text { Very } & & \\ & \text { strong } & \text { strong } & & \\ & \text { intention } & \text { intention } & & \end{array}$ at all

$468(26)$

655 (36)

$389(21)$

$181(10)$

$121(7)$

$2.45 \quad 1.21$

of the students considered it fairly or very probable, or had a fairly strong or very strong intent, to eventually become an entrepreneur. On the other hand, well over half of the students indicated the opposite view and opted for the alternatives very improbable or fairly improbable. In the case of all of the statements, approximately one fifth or one fourth chose the alternative "between".

\section{Results}

A linear regression analysis with a forced entry method was conducted: the score of entrepreneurial intent was set as the dependent variable and the six dimensions of abilities as the independent variables. Additionally, students' gender, age and field of study were included in order to control for their effects, and the field of study was transformed into ten dummy variables $(0=$ not present/not applicable, $1=$ present/ applicable). Although there were a few significant, albeit moderate, correlations among the independent variables (Table II), collinearity statistics suggested that the regression analysis was suitable for this data. Only with a very few cases the variance inflation factors were not $<10$ and the tolerances $>0.1$.

The model obtained, $\mathrm{F}(18,1,772)=28.96, p<0.001$, with adjusted $R^{2} 0.22$, involved seven significant predictors. As indicated in Table III, the participants with high self-perceived innovativeness, high ambitiousness-competitiveness, low academic abilities and low conventional employee skills scored relatively high on the entrepreneurial intent scale. Self-perceived extroversion and mental strength were not significant predictors $(p>0.10)$.

Furthermore, being a student of business studies was related to relatively high entrepreneurial intent, whereas being a student of nursing science was associated with relatively low entrepreneurial intent. Males showed higher intent than females.

\section{Discussion}

The present study contributes to the existing body of knowledge on university students' employability by scrutinising their positioning towards entrepreneurship in terms of their self-perceived abilities or "ability self".

As the descriptive statistics suggested, well over half of the participants considered it more or less improbable that they would become an entrepreneur at some phase of their career, whereas approximately one fifth of the participants considered this option to be 


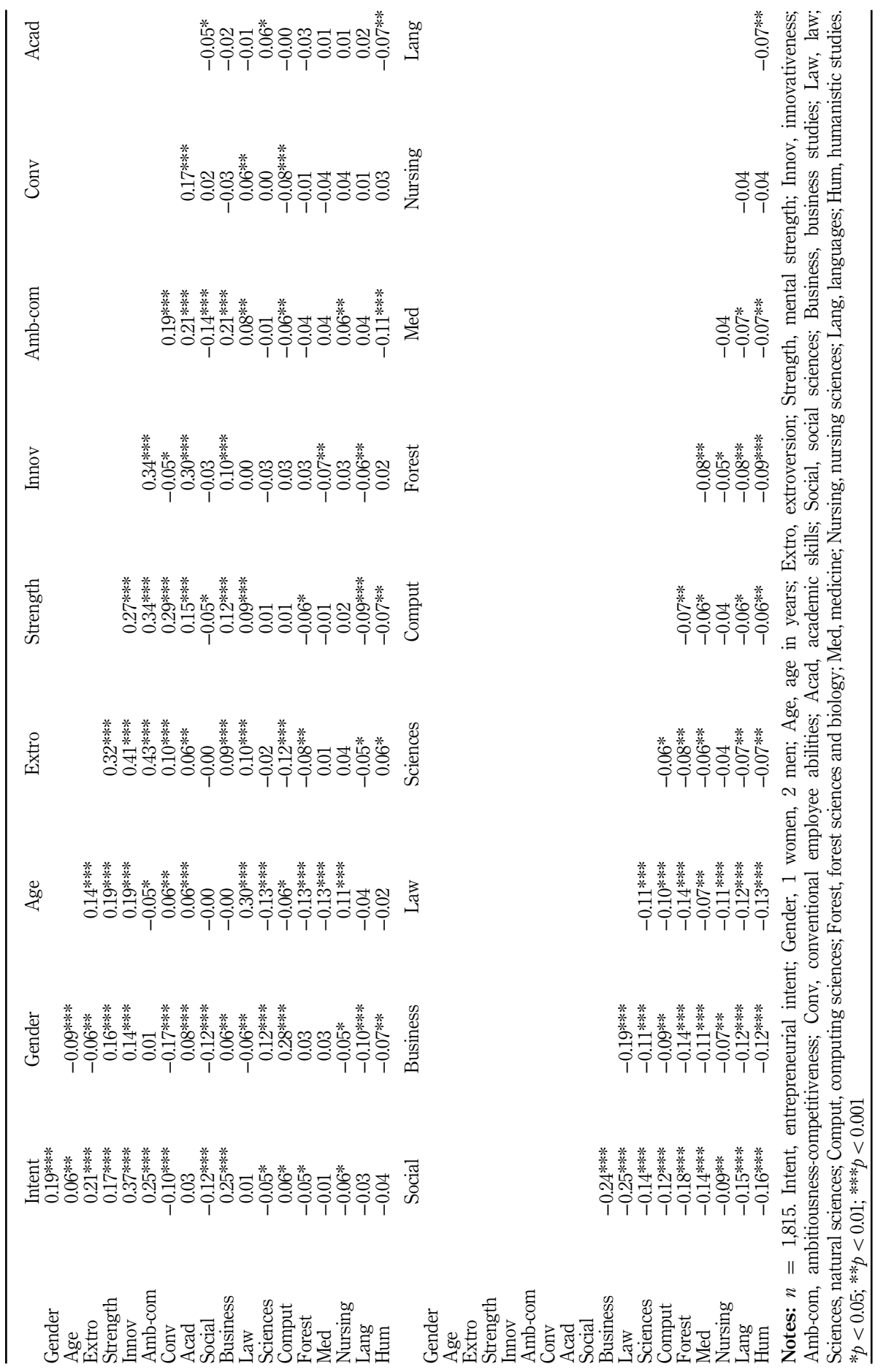

Entrepreneurial intent

903

Table II. Intercorrelations among the independent and dependent variables 
JARHE
11,4

Table III.

A summary of linear regression analysis

\begin{tabular}{|c|c|c|c|c|}
\hline \multirow{2}{*}{ Independent variables } & \multirow[b]{2}{*}{$\mathrm{SE}$} & \multirow{2}{*}{$\begin{array}{c}\text { Standardized } \beta \text { coefficients } \\
(\beta)\end{array}$} & \multicolumn{2}{|c|}{$95 \%$ confidence interval for beta $(\beta)$} \\
\hline & & & Lower bound & Upper bound \\
\hline Gender & 0.06 & $0.12 * * *$ & 0.19 & 0.41 \\
\hline Age & 0.01 & 0.03 & -0.00 & 0.01 \\
\hline Extroversion & 0.04 & 0.03 & -0.03 & 0.12 \\
\hline Strength & 0.04 & 0.03 & -0.02 & 0.13 \\
\hline Innovativeness & 0.04 & $0.28 * * *$ & 0.38 & 0.55 \\
\hline Ambitiousness-competitiveness & 0.04 & $0.11 * * *$ & 0.09 & 0.26 \\
\hline Conventional employee skills & 0.05 & $-0.08 * * * *$ & -0.29 & -0.08 \\
\hline Academic skills & 0.05 & $-0.08 * * *$ & -0.28 & -0.08 \\
\hline Social sciences & 0.20 & -0.07 & -0.58 & 0.21 \\
\hline Business studies & 0.21 & $0.14^{* * * *}$ & 0.05 & 0.86 \\
\hline Law & 0.21 & -0.01 & -0.43 & 0.38 \\
\hline Sciences & 0.22 & -0.04 & -0.64 & 0.22 \\
\hline Computing sciences & 0.23 & 0.02 & -0.35 & 0.55 \\
\hline Forest sciences and biology & 0.21 & -0.04 & -0.58 & 0.26 \\
\hline Nursing sciences & 0.25 & $-0.07 *$ & -1.00 & -0.02 \\
\hline Medicine & 0.22 & 0.01 & -0.42 & 0.44 \\
\hline Languages & 0.22 & 0.02 & -0.34 & 0.51 \\
\hline Humanistic studies & 0.22 & -0.02 & -0.50 & 0.34 \\
\hline Notes: $* p<0.05 ; * * p<0.01 ; *$ & $p<0$ & & & \\
\hline
\end{tabular}

fairly or very probable. Consequently, the present findings on students' reluctance to opt for entrepreneurship concur with those obtained in other studies (Akava, 2016; Ozaralli and Rivenburgh, 2016; Hisrich and Peters, 2002).

As we were dealing with university students, one fifth may well represent a relatively high prevalence of enterprising intent, although only about 7 per cent of the participants chose the alternative "very probable" or "very strong intention". This actually parallels the share of Finnish university-educated young people indicating a preference to function as an entrepreneur (Akava, 2016). Moreover, the present study revealed that about one fifth or one fourth of the participants did not indicate their inclination; some of these students may develop a motivation for entrepreneurship at a later time.

It was found that the students' perceptions of their abilities did pertain to their intent to become an entrepreneur. In line with our expectation based on the prevailing employability discourse, particularly innovativeness, but also ambitiousness and competitiveness, were associated positively with entrepreneurial intent, whereas a set of academic and conventional abilities showed a negative association. Thus, in terms of their self-rated abilities, the students who saw themselves as innovators and competitive-ambitious persons with no particular academic or conventional aptness were prone to position themselves as potential entrepreneurs on the basis of their entrepreneurial intent.

These ability identifications are not surprising when considering that competitiveness, ambitiousness and innovativeness, including risk taking, are generally regarded as central personal attributes connected with entrepreneurship (e.g. Çolakoğlu and İzlem Gözükara, 2016; Rauch and Frese, 2007). What was not expected was that the students' perceptions of conventional employee skills - such as being honest, conscientious and getting along with others - revealed an inverse association with entrepreneurial intent. We may ask whether conventional employee skills might be at odds with the assumed realities of entrepreneurship? Or are we dealing with a particular social categorisation through which enterprising-oriented students construe their social identity in order to maintain a distance from others (e.g. Jain et al., 2009), including the "ordinary" students?

Extroversion is usually considered to be an important ability requirement in modern working life (e.g. Sennett, 2006). Therefore, we expected that self-perceived extroversion would 
have evidenced a significant association with entrepreneurial intent. This did not turn out to be the case. We may speculate that although extroversion does not necessarily have a role in the construction of entrepreneurial intent, it may well represent a significant topical Entrepreneurial intent expectation that may even relate with students' employability optimism (Räty et al., 2018).

As the measure of academic abilities was psychometrically not good, we should be careful with our conclusions. The perceptions of these abilities seemed to suggest an inverse association with entrepreneurial intent. It appears that academic assets do not psychologically resonate constructively with the tenets of entrepreneurship (Komulainen et al., 2012). According to perceived abilities, entrepreneurship is in an academic context perceived as a rather restricted category to which only a few and specific individuals appear to have access (cf. Berglund and Johansson, 2007).

We can consider the social backgrounds of these contradictory relations at least in terms of national educational policy and academic identity. Concerning educational policy, the opposition between academic and entrepreneurial tenets is probably a more or less global phenomenon, but it may show up in different forms and intensity according to the various national higher educational systems. For example, we may speculate that the dilemma between academic and entrepreneurial spheres is currently quite activated in Finland where higher education policy has relatively recently adopted global neoliberal practices (Rinne, 2008; Rinne et al., 2014).

On the other hand, academic abilities such as theoreticality and intelligence are not just abilities. They pertain to a particular social identity which connects university graduates to their understanding of university education and an academic degree as personal validations of culturally the most highly appreciated theoretical abilities (Räty et al., 2017). This understanding is a convincing justification for a generalised tendency to perceive the social world in essentialist terms that are characteristic of people with high social status (Kraus and Keltner, 2013). This tendency also applies to Finnish university graduates (Authors). Given that academic abilities serve an important identity function in the upholding of social hierarchies social-psychologically constructed differences between the academic and entrepreneurial abilities are likely to remain as a true dilemma, causing continual tensions.

Our study has several limitations. First, cross-national comparisons are needed to establish the cultural specificity of the present findings. For example, the educational context shapes graduates' considerations and expectations of the competition for graduate jobs (Tholen, 2014). Even if entrepreneurial intent can be reliably identified in many countries according to the theory of planned behaviour (Engle et al., 2010; Ozaralli and Rivenburgh, 2016), different cultures have different ways to structure entrepreneurial intent and diverse ways to impact intents towards perceived feasibility and desirability (Sajjad et al., 2012).

Second, although the size of our sample was quite large, the response rate was relatively low, which is rather typical in e-surveys. In terms of representativeness, some fields of study were over-represented (various social sciences) and some fields were totally lacking (educational and technical sciences). Therefore, the observed extent of students' endorsement of entrepreneurial intent provides only a rather approximate estimate of the prevalence of that intent among all Finnish university students.

Third, the scale measuring academic abilities was psychometrically rather modest at best. Consequently, the category of academic abilities should be revised, although the delineation of what is a "true" academic ability is bound to remain somewhat uncertain. For example, "creativity" could be associated with academic research work or equally with enterprising-related "innovativeness". Fourth, the statements of intent scale represented only one category level of intents, i.e. that of career choice. Moreover, many people may engage in what might be considered entrepreneurial activities, even if they are not formally classified as entrepreneurs. Thus, a detailed scrutiny of what kind of concrete enterprise projects students have in mind may provide further knowledge about the construction of their entrepreneurial intent. 
JARHE 11,4
In this study, we found that the contribution of the students' perceptions of their abilities to their entrepreneurial intent was independent of other student characteristics such as gender and field of study. The finding that business studies students displayed relatively high entrepreneurial intent is a plausible one, and consequently gives a measure of validity to the intent scale. The effect of gender demonstrates that entrepreneurial intent is more common for males than females, indicating that entrepreneurship is still conceived as a masculine rather than a feminine sphere (Max and Ballereau, 2013). We need further studies to explore the social factors that impact women's possibilities to function as entrepreneurs in the same fields as men (e.g. Bhardwaj, 2017).

Our findings offer some scope for practical implications. Generally, as even the conventional research-based universities are transitioning towards entrepreneurial universities (Etzkowitz, 2014), the general approach to teaching is also changing, with education itself becoming more "entrepreneurial" (Welsh, 2014). Therefore, the understanding of what is "conventional" in the labour market might also shift over time; and employee skills in the "old" form would no longer be enough to succeed in the renewed labour market. This development implicates the need to critically evaluate academic teaching practices.

According to Moreau and Leathwood (2006), students are increasingly adopting an individualised employability discourse around their future employment. Because entrepreneurship appears to be conceived as an individualist and a rather circumscribed category the expansion of entrepreneurship education at universities may unintentionally further promote this discourse and the idea that students' career success as well as failure depend only on their personal characteristics.

Educators face the dilemma of how to in the best way link academic identity with the demands of working life, especially entrepreneurial intent and related skills. From the psychological viewpoint, it seems important to enhance students' trust in their potentials that has shown to be an essential factor in learning and studying in general (e.g. Dweck, 1999). Accordingly, universities should strengthen not only their students' practical readiness but also their academic identity, which entails abilities such as theoretical and analytical thinking and ability to learn.

\section{References}

Ahola, S. (2001), "Towards entrepreneurial workers? Transition from university to work in Finland", Journal of Institutional Research, No. 10, pp. 13-31.

Ajzen, I. (1991), "The theory of planned behaviour", Organisational Behavior and Decision Process, Vol. 50 No. 2, pp. 179-211.

Akava (2016), "Mitä korkeakoulutetut nuoret haluavat työelämältä [akava survey: highly-educated young people want stability from their working life]", available at: www.akavalainen.fi/ akavalainen/arjessa/tyoelamassa/mita_korkeakoulutetut_nuoret_haluavat_tulevaisuuden_ tyoelamalta (accessed 10 November 2018).

Berglund, K. and Johansson, A. (2007), "Constructions of entrepreneurship", Journal of Enterprising Communities, Vol. 1 No. 1, pp. 77-102.

Boden, R. and Nedeva, M. (2010), "Employing discourse: universities and graduate 'employability', Journal of Education Policy, Vol. 25 No. 1, pp. 37-54.

Brookover, W., Thomas, S. and Paterson, A. (1964), "Self-concept of ability and school achievement", Sociology of Education, Vol. 37 No. 3, pp. 271-278.

Clémence, A. (2001), "Social positioning and social representation", in Deaux, K. and Philogéna, G. (Eds), Representing the Social, Blackwell, Oxford, pp. 83-97.

Coetzee, M. (2017), "Graduates' psycho-social career preoccupations and employability capacities in the work context", in Tomlinson, M. and Holmes, L. (Eds), Graduate Employability in Context, Palgrave Macmillan, London, pp. 295-316. 
Çolakoğlu, N. and İzlem Gözükara, I. (2016), "A comparison study on personality traits based on the attitudes of university students toward entrepreneurship", Procedia - Social and Behavioral Sciences, Vol. 229 No. 19, pp. 133-140.

Dweck, C. (1999), Self Theories: Their Role in Motivation, Personality, and Development. Essays in Social Psychology, Taylor \& Francis, Howe.

Engle, R., Dimitriadi, N., Gavidia, J., Schlaegel, C., Delanoe, S., Alvarado, I., Xiaohong, H., Buame, S. and Wolff, B. (2010), "Entrepreneurial intent: a twelve country evaluation of Ajzen's model on planned behaviour", International Journal of Entrepreneurial Behaviour \& Research, Vol. 16 No. 1, pp. 35-57.

Etzkowitz, H. (2014), "The entrepreneurial university wave: from ivory tower to global economic engine", Industry and Higher Education, Vol. 28 No. 4, pp. 223-232.

Gareth, W. and Kitaev, I. (2005), "Overview of national policy contexts for entrepreneurialism in higher education institutions", Higher Education Management and Policy, Vol. 17 No. 3, pp. 125-141.

Goethrer, M., Obschonha, M., Silbereisen, R. and Gantner, U. (2012), "Scientists' transition to academic entrepreneurship: economic and psychological determinants", Journal of Economic Psychology, Vol. 33 No. 3, pp. 628-641.

Hisrich, R. and Peters, M. (2002), Entrepreneurship, McGraw-Hill, New York, NY.

Jain, S., Gerard, G. and Maltarich, M. (2009), "Academics or entrepreneurs? Investigating role identity modification of university scientists involved in commercialization activity", Research Policy, Vol. 38 No. 6, pp. 922-935.

Karabulut, A. (2016), "Personality traits on entrepreneurial intention", Procedia - Social and Behavioral Sciences, Vol. 229 No. 19, pp. 12-21.

Komulainen, K., Räty, H., Korhonen, M., Siivonen, P., Kärkkäinen, R. and Kasanen, K. (2012), “Changing discourses of employability", in Tolonen, T., Palmu, T., Lappalainen, S. and Kurki, T. (Eds), Cultural Practices and Transitions in Education, The Tufnell Press, London, pp. 92-94.

Komulainen, K., Räty, H., Korhonen, M., Siivonen, P., Kasanen, K., Rautiainen, R. and Kärkkäinen, M. (2015), “Kun Mikään ei Riitä': Akateeminen Kykyminä Puntarissa ('While nothing is enough': academic ability self in test)", in Brunila, K., Onnismaa, J. and Pasanen, H. (Eds), Koko elämä töihin: Koulutus tietokykykapitalismissa (Whole life at work: Education in present-day capitalism), Vastapaino, Tampere, pp. 145-172.

Kautonen, T., van Gelderen, M. and Flink, M. (2015), "Robustness of the theory of planned behavior in predicting entrepreneurial intentions and actions", Entrepreneurship Theory and Practice, Vol. 39 No. 3, pp. 655-674.

Kraus, M. and Keltner, D. (2013), "Social class rank, essentialism, and punitive judgment", Journal of Personality and Social Psychology, Vol. 105 No. 2, pp. 247-261.

Krueger, J., Reilly, M. and Carsrud, A. (2000), “Competing models of entrepreneurial intentions”, Journal of Business Venturing, Vol. 15 Nos 5-6, pp. 411-432.

Kurlin, A. (2018), "Maistereiden uraseuranta [A follow-up study of university graduates with MA], Aarresaari, Yliopistojen urapalvelujen verkosto [A network of universities' career guidance]", available at: www.unifi.fi/wp-content/uploads/2018/06/Yliopistojen-uraseurantatulokset_ Kurlin-ja-Suorsa-pdf (accessed 18 November 2018).

Lee-Ross, D. (2017), "An examination of the entrepreneurial intent of MBA students in Australia using the entrepreneurial intention questionnaire", Journal of Management Development, Vol. 38 No. 9, pp. 1180-1190.

Max, S. and Ballereau, V. (2013), "Theorizing about gender and entrepreneurship: bridging the gap with social psychology", International Journal of Gender and Entrepreneurship, Vol. 5 No. 1, pp. 97-110.

Moreau, M.P. and Leathwood, C. (2006), "Graduates' employment and discourse of employability: a critical analysis", Journal of Education and Work, Vol. 19 No. 4, pp. 305-324.

Mugny, G. and Carugati, F. (1989), Social Representations of Intelligence, Cambridge University Press, Cambridge. 
JARHE 11,4

Nurmi, P. and Paasio, K. (2007), "Entrepreneurship in Finnish universities", Education+ Training, Vol. 49 No. 1, pp. 56-65.

Ozaralli, N. and Rivenburgh, N. (2016), "Entrepreneurial intention: antecedents to entrepreneurial behaviour in the U.S.A. and Turkey", Journal of Global Entrepreneurship Research, Vol. 6 No. 1, pp. 1-32.

Prokou, E. (2008), “'The emphasis on employability and the changing role of the university in', Europe”, Higher Education in Europe, Vol. 33 No. 4, pp. 387-394.

Rauch, A. and Frese, M. (2007), "Let's put person back into entrepreneurship research: a meta-analysis on the relationship between business owners' personality traits, business creation, and success", European Journal of Work and Organizational Psychology, Vol. 16 No. 4, pp. 353-385.

Rinne, R. (2008), "The growing supranational impacts of the OECD and the EU on national educational policies, and the case of Finland", Policy Futures in Education, Vol. 6 No. 6, pp. 665-680.

Rinne, R., Jauhiainen, A. and Kankaanpää, J. (2014), "Surviving in the ruins of the university?", Nordic Studies in Education, Vol. 34 No. 3, pp. 213-232.

Räty, H., Mononen, N. and Pykäläinen, E. (2017), "Essentialism and social representations of intelligence", Social Psychology of Education, Vol. 20 No. 4, pp. 915-927.

Räty, H. (2015), "Notion of intelligence and social-educational identity", Educational Studies, Vol. 41 No. 3, pp. 272-275.

Räty, H., Komulainen, K., Halvérson, C., Nieminen, A. and Korhonen, M. (2018), “University students' perceptions of their 'ability selves' and employability: a pilot study", Nordic Journal of Studies in Educational Policy, Vol. 4 No. 2, pp. 107-115.

Räty, H., Korhonen, M., Kasanen, K., Komulainen, K., Rautiainen, R. and Siivonen, P. (2016), "Finnish parents' attitudes towards entrepreneurship education”, Social Psychology of Education, Vol. 19 No. 2, pp. 385-401.

Rothwell, A., Herbert, I. and Rothwell, F. (2008), "Self-perceived employability: construction and initial validation of scale for university students", Journal of Vocational Behavior, Vol. 73 No. 1, pp. 1-12.

Sajjad, S., Shafi, H. and Dad, A. (2012), "Impact of culture on entrepreneur intention", Information Management and Business Review, Vol. 4 No. 1, pp. 30-34.

Schlaegel, C. and Koenig, M. (2014), "Determinants of entrepreneurial intent: a meta-analytic test and integration of competing models", Entrepreneurship Theory and Practice, Vol. 38 No. 2, pp. 291-332.

Sennett, R. (2006), The Culture of New Capitalism, Yale University Press, Yale.

Siivonen, P., Komulainen, K., Räty, H., Korhonen, M., Kasanen, K. and Rautiainen, R. (2016), "Salvation of broken promise? Two adult graduates' social positioning in education and working life", Scandinavian Journal of Educational Research, Vol. 60 No. 1, pp. 110-125.

Tholen, G. (2014), "Graduate employability and educational context: a comparison between Great Britain and the Netherlands", British Educational Research Journal, Vol. 40 No. 1, pp. 1-17.

Thompson, E. (2009), "Individual entrepreneurial intent: construct clarification and development of an internationally reliable metric", Entrepreneurship Theory and Practice, Vol. 33 No. 3, pp. 669-688.

Tomlinson, M. (2008), “The degree is not enough': students' perceptions of the role of higher education credentials for graduate work and employability", British Journal of Sociology of Education, Vol. 29 No. 1, pp. 49-61.

Tomlinson, M. (2012), "Graduate employability: a review of conceptual and empirical themes", Higher Education Policy, Vol. 25 No. 4, pp. 407-431.

Tonttila, K. (2010), "Yrittäjyyden Arvottaminen Akateeemisten Nuorten Puheessa [Evaluation of entrepreneurship in the speech of academic students and newly qualified young academics]", University of Helsinki, Helsinki, available at: http://urn.fi/URN:ISBN:978-952-10-6611-5 (accessed June 2019).

Vivas, A. and Alvarez-Hevia, D. (2017), "Paths, patterns and factors that influence the entry of university graduates into labour market”, European Journal of Higher Education, Vol. 7 No. 4, pp. 388-401. 
Welsh, D. (2014), Creative Cross-Disciplinary Entrepreneurship: A Practical Guide for a Campus-Wide Entrepreneurial Program, Palgrave Macmillan, New York, NY.

Wood, M. (2011), "A process model of academic entrepreneurship”, Business Horizons, Vol. 54 No. 2, pp. 153-161.

\section{Further reading}

Bhardwaj, B.R. (2018), "Can education empower women through entrepreneurial marketing: a model for upliftment of community services", Journal of Enterprising Communities: People and Places in the Global Economy, Vol. 12 No. 1, pp. 19-31.

Iakovleva, T., Kolvereid, L. and Stephan, U. (2011), "Entrepreneurial intentions in developing and developed countries", Education+Training, Vol. 53 No. 5, pp. 353-370.

Taulu, H. (2017), "Tilastoja korkeasti koulutettujen työttömyydestä [statistics of the unemployment among high-educated persons]", available at: www.akava.fi/files/12516/01_Tilastoja_korkeasti_ koulutettujen_tyottomyydesta_yleisimmat_asteet.pdf (accessed 18 November 2018).

\section{Corresponding author}

Hannu Räty can be contacted at: hannu.raty@yahoo.com

For instructions on how to order reprints of this article, please visit our website: 